\title{
Retaining multi-functionality in a rapidly changing urban landscape: insights from a participatory, resilience thinking process in Stockholm, Sweden
}

\author{
Sara Borgström $^{1}$ Erik Andersson $^{2,3}$ and Tove Björklund ${ }^{1}$
}

\begin{abstract}
Urban social-ecological resilience research has focused on conceptual explorations, while less attention has been paid to how resilience thinking in practice may inform urban development. Using the rapidly urbanizing landscape in Stockholm as a case, we explore the urban specifics of resilience thinking practice and thereby contribute to the development of knowledge and practice of social-ecological resilience thinking generally. The study addresses an urban wicked problem: how to ensure that people continue to have access to the means necessary to realize benefits from green blue infrastructure, when the city is changing and governance is fragmented. Drawing on insights from the design and implementation of a participatory dialogue process, we outline methodological adaptations to a resilience informed system exploration, to better accommodate the complexity of urban systems. The participatory process included three phases: basic system understanding, dealing with change over time, and identifying alternative ways forward. Different knowledge elicitation and deliberation methods were deployed within workshops, surveys, and interviews, and were paralleled by a thorough reflexive analysis of process outcomes. The main discussion points are stakeholder participation, the role of discourses, identities and mandates, agency, and adaptive capacity, and alternative strategies for dealing with change. Deep knowledge of the complexities of urban land use and governance requires the involvement of diverse stakeholders. Handling this diversity poses a challenge for process design: combining the ambition of an inclusive process and the need to be relevant with the use of bridging concepts increases the risk of reducing the level of complexity of the deliberative process. There is also a risk of participation bias, where stakeholders knowledgeable about the green blue infrastructure are easier to engage compared to stakeholders with knowledge about drivers of change and urban governance, which will influence the system understanding and envisioned alternative pathways for taking action.
\end{abstract}

Key Words: agency; collective capacity; densification; green and blue infrastructure; participatory methods; process design; reflexive practice; scenarios; urban social-ecological resilience

\section{INTRODUCTION}

Nature provides humanity with many essential benefits. In cities, green and blue infrastructure (GBI), i.e., all the functionally connected green and blue elements of the urban landscape (Pauleit et al. 2019), is the principal source of human well-being benefits such as shade, air pollution mitigation, flood control, nature education, and relaxation (Bolund and Hunhammar 1999, Gómez-Baggethun and Barton 2013, Haase et al. 2014). When cities grow denser and the extent and number of green spaces decrease, each GBI element is increasingly expected to provide multiple benefits (Hansen and Pauleit 2014, Hansen et al. 2019). This is placing a high demand on both ecological functionality and governance arrangements that can help promote multifunctionality (Buijs et al. 2016, Hansen et al. 2019). Less discussed is how inherently diverse and changeable GBI is, and how it is supposed to continuously provide multiple benefits in rapidly changing cities. Internal and external pressures and drivers of change, such as urbanization and climate change, require a high degree of flexibility and resilience (Elmqvist et al. 2018). According to, among others, Biggs et al. (2012), broad participation is a key general principle to support such capacity. We address the question of what kind of deliberation processcontent, design, and participants - could help secure long-term, critical urban ecosystem services.

Resilience is an umbrella term and framework used within many different branches of sustainable development scholarship and practice, and urban sustainable development is no exception
(Meerow et al. 2016, Elmqvist et al. 2019). Resilience, as used here, means the system's capacity to retain function and continue to develop along a desired trajectory (sensu Elmqvist et al. 2019). From its origin in ecosystem ecology and natural resource management, the theories behind social-ecological (SE) resilience advanced to address and conceptualize the relationship and feedbacks between humans and biotic natural resources (Folke 2006). Today, the application of resilience in practice, resilience thinking, has three different aspects: systems understanding, systems assessment, and building systems resilience (Biggs et al. 2012, Walker and Salt 2012, Sellberg et al. 2018). Increasing use has led to the development of different tools for helping people identify ways to build SE resilience around sustainable development, e.g., the Wayfinder guide (Enfors-Kautsky et al. 2018). Following the assertion that plurality of types of knowledge need to be acknowledged and invited to the process to ensure that actionable new knowledge is generated (Cash et al. 2003, Tengö et al. 2014, Sellberg et al. 2018), this practice of resilience thinking often takes the form of participatory processes.

Urban SE resilience is widely discussed and conceptually rich (Pickett et al. 2004, McPhearson et al. 2015, Meerow et al. 2016, Elmqvist et al. 2019), but its practices have not yet been thoroughly explored. Compared to the complex systems that have informed the development of SE resilience thinking, e.g., coral reefs, lakes, or forests, direct dependence on local so called provisioning ecosystem services is much less pronounced in urban

\footnotetext{
${ }^{1}$ Department of Sustainable Development, Environmental Science and Engineering, KTH Royal Institute of Technology, Stockholm, Sweden, ${ }^{2}$ Stockholm Resilience Centre, Stockholm University, Stockholm, Sweden, ${ }^{3}$ North-West University, Unit for Environmental Sciences, Potchefstroom, South Africa
} 
Fig. 1. Map of the Flaten Landscape and its location in relation to Stockholm.

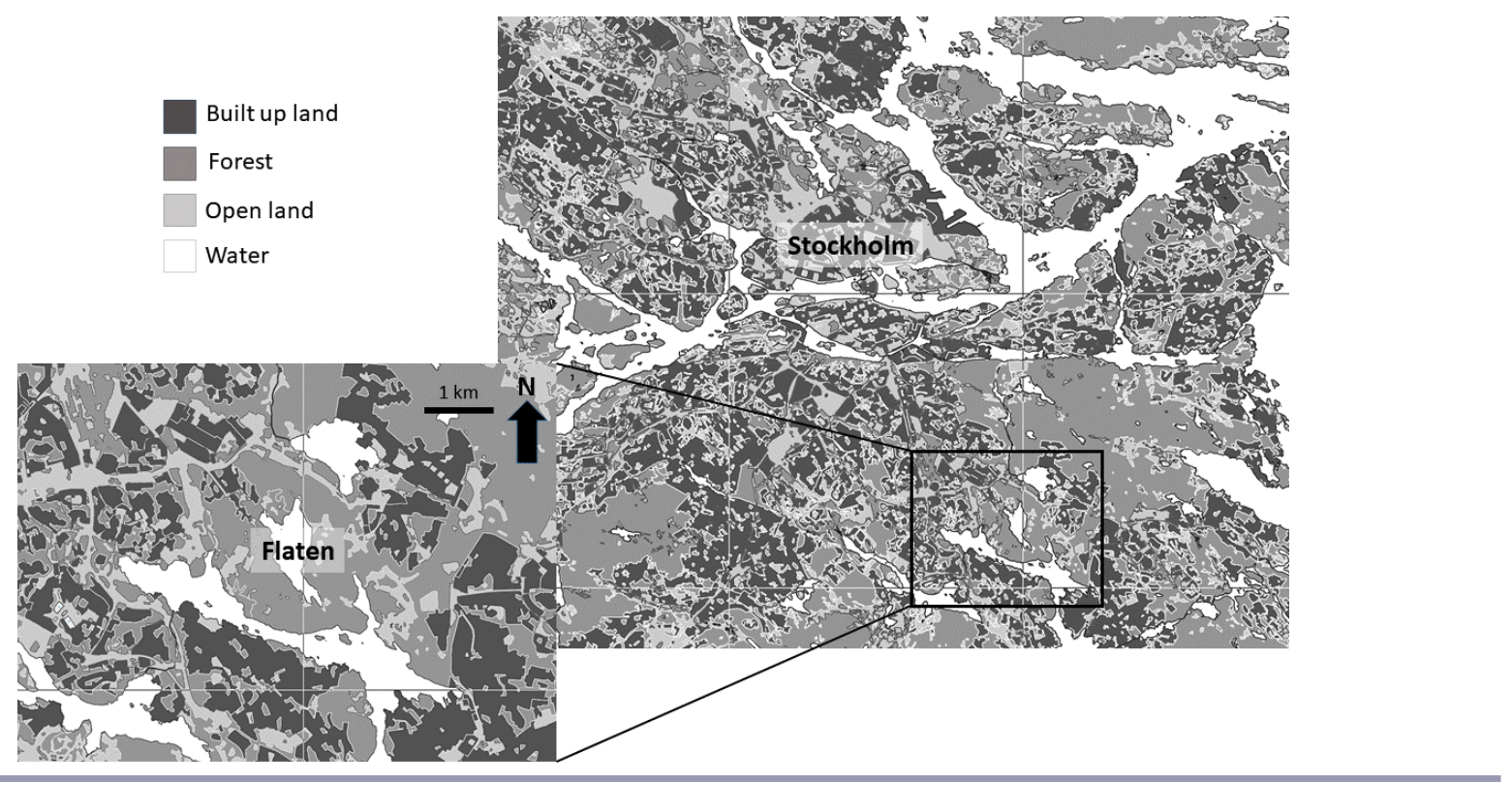

systems. Traditionally, the main benefits associated with urban GBI are experiential, and hence dependent on both availability and accessibility of GBI and, equally important, the perceptions of the beneficiaries (Andersson et al. 2015, Dickinson and Hobbs 2017). Furthermore, compared to systems based on direct use of local natural resources, the primary mechanism influencing the flow of benefits from the urban GBI to the city dwellers is multitarget land use governance and the institutional thickness of cities (Amin and Trift 1995, Wolfram 2018). This means a governance characterized by multiple levels, sectors, and actors that are intricately intertwined. However, it often has limited capacity to recognize the interactions of urban life across their domains, and where disconnections are key barriers to any holistic approaches (Ehnert et al. 2018, Borgström 2019). Here, SE resilience thinking can support urban sustainable development by not only capturing the system dynamics and complexity of GBI functioning in urban settings, but also the multiple relations between social and ecological aspects of this urban system. In this paper, these relations are described as the flow of benefits from urban GBI to urban residents (beneficiaries) following the conceptual model outlined by Andersson et al. (2019) and the SE co-production logic proposed by, for example, Palomo et al. (2016) and Dickinson and Hobbs (2017).

Given the importance of urban systems to global sustainable development in general and cities being the dominating human habitat, there is a need to add to the conceptual understandings of urban GBI resilience and develop resilience thinking practices for urban landscapes. Based on insights from designing and undertaking a participatory resilience thinking process in a complex and changing city district in Stockholm, Sweden, we aim first to explore how resilience thinking can contribute to the GBI state of the art conceptualization (Grimm et al. 2015, McPhearson et al. 2015, Zhou et al. 2017, Andersson et al. 2019). Second, it describes how resilience thinking was applied to identify and support strategies for safeguarding GBI benefits in the midst of ongoing urban densification and redefinition, as well as repositioning of GBI. Finally, it outlines critical points for making the practice of resilience thinking fit with the urban context.

\section{THE FLATEN LANDSCAPE CASE}

The Flaten landscape (FL) is located southeast of central Stockholm, the capital of Sweden. Stockholm is one of the fastest urbanizing regions in Europe (Lavalle et al. 2017), where densification and spatial expansion results in infill development, as well as encroachment and appropriation of GBI (Furberg 2019). In addition, increasing population density is putting pressure on the GBI to support the generation and mediation of multiple benefits to an increasingly large and diverse group of beneficiaries.

The FL is not defined by any existing boundary, neither physical nor administrative; instead, it seeks to capture the landscape context of a central GBI feature, a formally protected nature reserve and a $1 \mathrm{~km}$ zone outside its boundary, located at an intersection of three municipalities (Fig. 1). In addition to the nature reserve, the GBI in the FL consists of a mosaic of different kinds of green elements. It provides a clear case of SE coproduction of benefits because all GBI in the FL is semi-natural and human activities have influenced the landscape for centuries. The urban fabric consists of several relatively isolated, residential areas including local service facilities and some work places. In line with the regional strategy for urban development emphasis on densification, the FL has several detailed development plans for infill development and appropriation of larger pieces of undeveloped land. The governance of the FL exemplifies the high degree of decentralization and sectoral organization of public administration in Sweden: First, there are no legal requirements for municipal coordination beyond stated national interests, even if many collaborative efforts are made and recommended from the regional level. Second, different land uses are planned and 
managed by different sectors following own policies and practices, e.g., built-up land, outdoor spaces in-between buildings, and nature protected areas. There are generally few incentives for collaboration between public and private landowners.

In response to overall societal trends and changes in the character of the urban development the overall demography in Stockholm is changing, which leads to new or altered demands for different benefits, e.g., new ways of GBI use, and adjustments for increased accessibility. These drivers of change indicate a need to explore new ways of understanding GBI and using nature protected areas as embedded parts of mosaic urban landscapes, which is increasingly acknowledged by different actors. One reason for choosing the FL as a case study area was that the Stockholm municipality in 2016 led a one-year pilot project in the area with the aim of investigating how nature reserves could be adjusted to keep in step with the ongoing urbanization and become more accessible (Stockholm Stad 2016). The researcher team participated in this pilot project where the output, including background material, a dialogue process, and a final report, was an important starting point for the participatory process presented in this paper.

\section{A PARTICIPATORY, RESILIENCE THINKING PROCESS}

The participatory process in the FL was initiated and led by the research team and was also one of several case studies within a larger research project about urban GBI (see Andersson et al. 2021a, b, this Special Feature). Based on the research questions and the societal interests expressed by key informants in the FL, the overarching process aim was to explore joint processes for how to maintain a wide spectrum of GBI functions for a growing population despite urban densification and decreasing extent and accessibility of GBI. The identified process goals were to explore how to strengthen and build resilience around co-created, naturebased recreational benefits and overcome the challenges of a fragmented governance system. These goals were based on the research team preunderstanding gained through the pilot project (see above) as well as ongoing dialogues with key informants (Appendix 1). The design of the knowledge co-creation process, as outlined in Figure 2, was based on a resilience thinking in practice approach (Sellberg et al. 2017, 2018, Enfors-Kautsky et al. 2018), first described in the resilience assessment framework (Resilience Alliance 2010). Theoretically, this approach is grounded in a complex system perspective focusing on change, cross-scale interactions, and adaptive capacity (Folke et al. 2002, Walker and Salt 2012). It is an open, flexible, multi-step process based on sequential stakeholder deliberations. The process is designed to develop a shared understanding of (a) system configuration and baseline, including target definitions, key values and boundary objects, main current challenges, central actors and factors; (b) system dynamics, including changes over time, drivers, thresholds, scales, alternative future scenarios; and finally (c) strategies for moving forward, e.g., what actions to prioritize and who might influence what changes, and for building anticipatory and adaptive capacity by formulating contingency plans (see also Andersson et al. 2021a, this Special Feature). The FL process design used the Workbookfor Practitioners (Resilience Alliance 2010) as a starting point but with adaptations inspired by the work of Sellberg et al. $(2015,2017,2018)$, the resilience principles (Biggs et al. 2012), multi-criteria evaluation (e.g.,
Munda 2006, Langemeyer et al. 2018), and the Wayfinder online platform (Enfors-Kautsky et al. 2018).

The participatory resilience thinking (pRT) process in the FL had at its core four thematic workshops that were hosted and led by the research team. Each workshop was organized around several tasks aligned with the pRT steps above, using a variety of participatory dialogue methods, and documented by note taking and photographing of drawings and post-it clustering, etc., which was done either by the research team or the participants themselves (Appendix 1 for participants, Appendix 2 for general workshop outline). A summary of the documentation was sent to registered participants after each workshop. To ensure opportunities for individual reflection and diversity of opinions, two surveys were sent out to complement the workshops, one as a follow up to workshop 1, and one for evaluating the participatory process (Fig. 2, Appendix 3 for survey questions). For the same reasons, the participatory process was closed by semi-structured interviews with five key informants with in-depth questions about the outcomes of the process and the next steps (Appendix 1, Appendix 3 for questions). In total, 39 stakeholders were involved in the process, but with different level of participation. Some participated in all interactions and others in just one or a few (Appendix 1). The pRT process was concluded with a complete summary sent to all participants. As outlined in Figure 2, between each interaction with stakeholders, the research team processed the collected material through joint reflection meetings discussing not just content outcomes, but also the process itself, e.g., the stakeholder group dynamics, engagement process, the progress of system understanding and learning, and the adaptations and adjustments made along the way. These meetings were documented by written notes, and throughout the pRT process all material (from workshops, surveys, research team processing, and reflections) was compiled into an internal report, which formed the basis for the synthesizing reflection presented below.

\section{Phase 1. Basic system understanding}

This phase in the pRT process aimed to establish the target ("resilience of what"), to set the scope and boundaries for the study, and to identify what knowledge would be needed to build a systems understanding for addressing this target (Resilience Alliance 2010). In the FL case, this meant understanding the local configuration of the GBI-benefits-beneficiaries nexus, i.e., users of GBI benefits, actors, and factors influencing the co-production of benefits, and the landscape governance directing the generation, flow, and distribution of these benefits. The time frame was set to match the timescale of present policies for the landscape (until 2050), and the spatial extent was set at a city district scale that spans and bridges land use and administrative boundaries to make sure the discussions always included the complexity of the urban governance challenge of connecting across boundaries.

The initial system mapping of the FL included information about (1) land use, stakeholders, and previous and ongoing governance processes, e.g., policy-making, urban planning, resident dialogues, local initiatives, and (2) the scope and ambit of different policy spheres/sectors. Data were generated through researcher expertise and key informant consultation together with 
Fig. 2. The three phases of the participatory resilience thinking process. Grey rectangles are activities by the research team, blue circles are outcomes from the previous activity and that is used in the following one, orange ovals are interactive activities with the research team and stakeholders, white rectangles present the aim of the interactive activity. WS1, WS2, WS3 = first, second, third workshops; GBI - green and blue infrastructure.

\section{BASIC SYSTEM UNDERSTANDING}

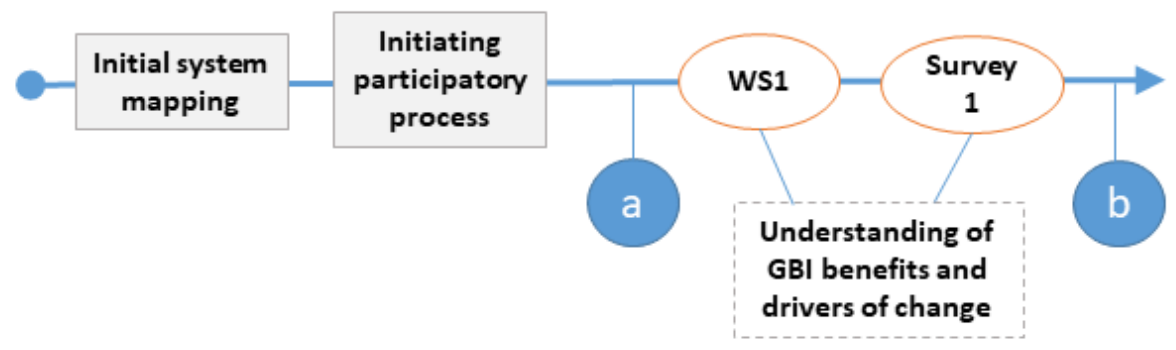

\section{DEALING WITH CHANGE OVER TIME}

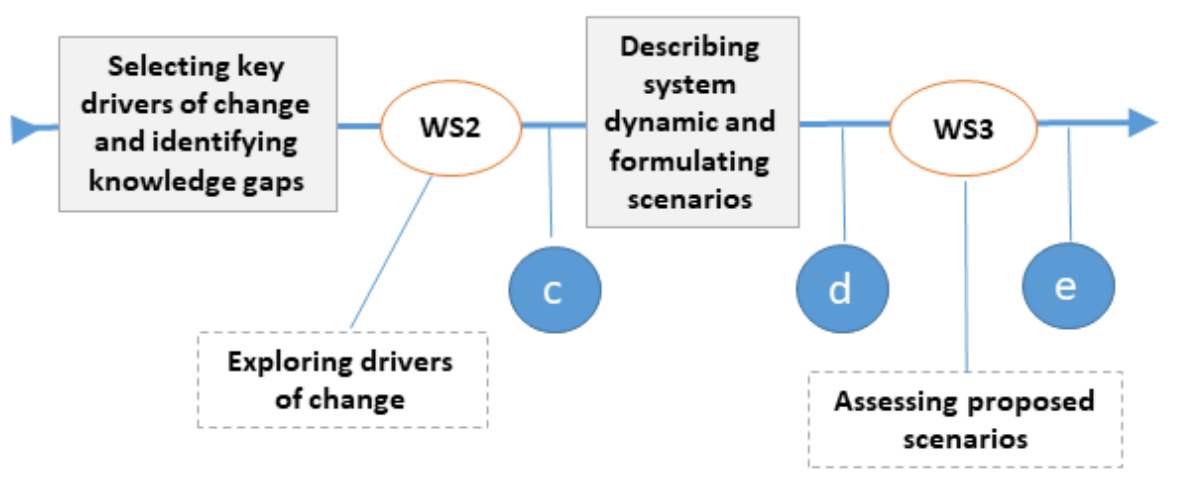

\section{IDENTIFYING ALTERNATIVE WAYS FORWARD}

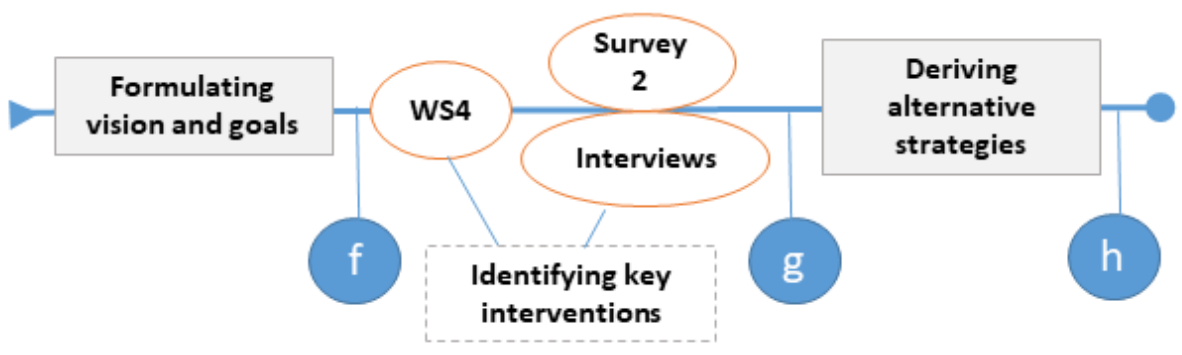

a) Information about ongoing governance processes and a list of stakeholders

b) List of benefits, preconditions for those benefits, and key drivers of change

c) Text-based narratives about drivers of change and their interactions

d) Four narrative scenarios based on drivers of change and preconditions for benefits

e) Identification of benefits relevant as starting points for discussing ways forward

f) Vision and goals for a resilient GBI supporting identified benefits and their preconditions

g) Suggested measures for building capacity a resilient GBI

h) Actions clustered into themes for strategic action 
stakeholder mapping (including snowballing) and a scoping review of policy documents (Appendix 4). The outcome was a system description including ongoing processes in relation to GBI and urbanization, as well as a list of stakeholders (a in Fig. 2). The process identified a first key constraint to both the current management of multi-functionality and benefit co-production, and the capacity to respond to change: the prevailing densification strategy that reduces the connectivity and extent of the GBI while increasing the demands for a broader range of GBI functions and benefits. In parallel with, and amplified by, the ongoing densification, Stockholm has a strong sectoral approach to governance where there is a clear divide between built up areas and green, open space. This land use change and disconnected governance often results in intense (costly) management of a few targeted green spaces, where there is a high risk of trade-offs between benefits.

The district scale together with the ambition to catalyze crosssector, multi-actor dialogues drawing on a wide range of knowledge, required the research team to develop a language and framing that related resilience thinking concepts to themes and topics directly recognizable and relevant to local actors (in line with Tuinstra et al. 2019). Informed by the policy review (Appendix 4) and key informant consultation, the co-production of recreational benefits of GBI were framed as nature-based recreational activities and the preconditions they require (Borgström, Andersson, and Björklund, unpublished manuscript). Building on this conceptualization, the first workshop (WS1, Fig. 2, Appendix 2) provided more local specificity, detail, and nuance to the initial system understanding and anchored the basic system/ problem description with the participating stakeholders (b in Fig. 2). Of all stakeholders invited, 25 participated (Appendix 1) in the carefully designed and facilitated participatory workshop, and 16 of them responded to a complementary online survey (Appendix 3). The two deliberations generated a list of appreciated nature-based recreational activities in the FL and the preconditions necessary for these activities (b in Fig. 2). The nature-based recreational activities identified in the FL were very different, ranging from everyday walks, swimming, and picnicking, to more "advanced," such as bouldering and skating, i.e., requiring more extensive practitioner knowledge and certain equipment.

Furthermore, the workshop identified what was seen as the most relevant drivers of change, and these were thematically grouped into climate change, urbanization by exploitation, transport infrastructure developments, increasing population and changed demography, prioritization of public funds, prioritization of measures in the GBI, and planning and implementation of measures in GBI. The participants perceived themselves as having very little influence on any of the drivers. They thought that urbanization by housing development, increasing population, and changed demography, together with planning and implementation of measures (management, provision of facilities, etc.) in GBI had the most impact on the identified nature-based recreational activities. Many pRT processes aim at finding ways to handle changes that are directly experienced as negative, or as real threats, which directs the process toward transformation away from a present, undesirable state (Resilience Alliance 2010, Enfors-Kautsky et al. 2018, Sellberg et al. 2018). In the FL case, the appreciated benefits were not perceived as under direct threat by the identified changes, and hence the goal was to build an understanding of the dynamics and necessary conditions behind the generation of benefits (in order to support the stakeholders in developing a vision for the landscape as well as in identifying alternative pathways, in the form of strategies, toward this vision).

\section{Phase 2. Dealing with change over time}

The second phase of the pRT process in the FL developed a deeper understanding of temporal dynamics and change in the system. At the core was the objective to increase the understanding of how the co-production of GBI recreational benefits changes, or could change, over time. The drivers of change identified in phase 1 (above) were in this second phase connected both to their potential influence on the different recreational benefits (through changes in the landscape structure as well as in the people using it) and to the relevant governance policies and actors. The overarching methodology in this phase was development, iterations, and discussions about different future scenarios (Falardeau et al. 2019).

Based on an assessment of salience of the material from phase one, and connections to the overall conceptual framing, the research team selected four key drivers: (1) urban development, (2) environmental and climate change, (3) forms of housing tenure, and (4) governance organization and decision making. A second, facilitated participatory workshop was then carried out to explore and better understand what was changing in the FL, how the drivers of change interact and potentially shape the future character of FL in 2050 (WS2 in Fig. 2, Appendix 2). The participants were asked to develop several future scenarios for the FL 2050 where each scenario included different expressions of all four drivers. Because the workshop aimed at understanding change, and potentially system thresholds, the facilitators encouraged the participants to play with the extreme developments and outcomes, regardless of whether or not these were seen as likely. The workshop produced a number of textbased, narrative descriptions of the drivers of change and their potential interactions (c in Fig. 2).

In order to build an understanding about how the changes, framed as possible futures, might influence the flow of nature-based recreational benefits from GBI, a third workshop was organized (WS3 in Fig. 2, Appendix 2). In preparation for this facilitated, participatory workshop, the research team used thematic similarities to condense the scenarios from WS2 into four narrative scenarios capturing the complex dynamics of the identified four key drivers and their relation to preconditions for nature-based recreational activities (d in Fig. 2). The participants discussed how actions should be prioritized in each scenario to support a broad access to nature-based recreational activities in the FL, and also reflected upon what activities could be used as starting points for working toward a resilient GBI in the FL (e in Fig. 2, Appendix 2).

During and after the workshops the participants expressed difficulties with thinking about and anticipating the effects of change and a perceived deficiency of knowledge about some of the drivers. They also struggled to think beyond change as a threat to GBI and identify possibilities and new opportunities related to the drivers. Furthermore, the third WS again opened up for system complexity; each scenario displayed several combinations 
of drivers and preconditions, where each nature-based recreational activity interacted with these in a unique way (coproduction process), and where it was also highlighted how the activities were interrelated. In addition, the broad participation meant a wide diversity of ways of relating to this complexity and ability to discuss it. It was also evident that the FL was not perceived as changing rapidly or having changed rapidly in recent times, therefore notions of abrupt changes and shifts were absent in the discussions.

\section{Phase 3. Identifying alternative ways forward}

By exploring constraints, barriers, opportunities, and pathways forward, the final phase of a pRT aims to derive or outline purposeful responses based on the systems understanding in relation to the identified target (Resilience Alliance 2010, EnforsKautsky et al. 2018). In this process, the research team drafted a vision and a set of goals for the future of the FL in 2050. The vision was built on four prerequisites for a resilient GBI future, in combination with our accumulated knowledge and the joint discussions on target values, changes, possible futures, needs, and challenges throughout the pRT-process, as well as pre-conditions to support and promote the prioritized activities (f in Fig. 2). These, in combination with scientifically identified factors central for coping with change (Biggs et al. 2015), previous targets that have been formulated for the FL (Stockholm Stad 2016), and the Government's Strategy for Living Cities (Swedish Government 2017), constituted a draft version of the vision, which was then sent to key informants for refinement and validation (Appendix 1).

The final participatory workshop (WS4 in Fig. 2, Appendix 2) and complementing interviews with key informants (Appendix 1, Appendix 3) focused on alternative ways to reach the desirable system configuration, i.e., vision and goals, and to identify what actions to prioritize to start to build resilience around these different pathways. Participants discussed what actions should or could be taken, and by whom, where in the FL and at what level, and formulated a number of change strategies for each goal description. They also specified what should be maintained (as it is today), adapted and/or transformed (i.e., fundamentally changed), or if anything should be excluded (i.e., undesirable system components). The suggestions covered a wide range of different actions from very concrete improvements to revisions of national legislation and strategies for governance transformation ( $\mathrm{g}$ in Fig. 2). The majority of the suggested changes and interventions concerned governance and institutions, reinforcing again the challenge of the urban context and the fragmented governance and institutional thickness of the FL described in phase 1 . The output was analyzed by the research team through an iterative process where the identified preconditions for activities were used as an initial sorting frame (h in Fig. 2). Several stakeholders suggested a jointly formulated comprehensive action plan for the FL; however, it was found very difficult to determine who could or should lead such a process. Through an online survey, the participants evaluated the pRT process regarding perceived outcomes including learning, participation, and new actor connections (Appendix 3).

\section{PROCESS REFLECTIONS}

The FL pRT was paralleled with the application of a reflexive practice by the research team (Wittmayer and Schäpke 2014), where some of the reflections are of particular relevance for resilience thinking in urban development practice and processes, and for how to nurture GBI resilience in urbanizing landscapes targeting multiple, co-produced benefits in complex governance contexts.

\section{An urban stakeholder palette}

Broad stakeholder participation has been identified as a key principle for building resilience (Leitch et al. 2015). Inclusion of multiple stakeholders can improve the systems understanding (Tengö et al. 2014), support long-term learning (Pahl-Wostl 2009) and transformative capacity (Wolfram 2016), and improve process legitimacy (Plummer and Fitzgibbons 2004), and thereby increase the relevance and usefulness of the knowledge developed within a pRT process. Such generic, potential benefits of stakeholder participation are also highlighted in the context of urban sustainable development, e.g., collaborative planning (Healey 1997), mosaic governance (Buijs et al. 2016), urban civic ecology (Krasny et al. 2014), and stewardship (Andersson et al. 2014, 2017). However, as is well described in literature about transdisciplinary research, and later knowledge co-production and co-creation, these resilience building outcomes are dependent on the process dynamics of the participation, e.g., who is included, the process framing, design, and methods, and diverging interests and power relations between the participants (Lang et al. 2012, Polk 2014, Sarkki et al. 2014, Djenontin and Meadow 2018, Turnhout et al. 2020).

In the case of the FL, "stake" was defined by the conceptual model of nature-based recreational activities (GBI benefits), necessary preconditions for these activities, and their potential benefits (filters) and users (beneficiaries) in an urbanizing landscape (Andersson et al. 2019; Borgström, Andersson, and Björklund, unpublished manuscript). The recreational activities identified in the FL were internally very different and hence had different user profiles and depended on a diverse range of preconditions. Each nature-based recreational activity meant inclusion of different, although sometimes overlapping, sets of stakeholders. Beside users, the process engaged stakeholders with formal responsibility for, or influence on, the necessary preconditions, e.g., those involved in the planning and management of GBI and/or GBI benefits, as well as other land uses at different administrative levels in the FL. With multi-level and sectorally divided governance mandates, this meant inclusion of a significant number of stakeholders. In summary, the diversity of stakeholders in the FL process was very high, reflecting the overarching system approach of resilience thinking in combination with the urban landscape character.

Embedded in this stakeholder diversity were differences of importance for the process outcomes, e.g., in purpose for engaging in the process, in ability and mandate to use the outcomes to change present situation in the FL, in type of knowledge, in experience of participatory processes, and in ability to discuss visions and strategies. Furthermore, there were large differences in the reasons and conditions for participation, e.g., some stakeholders used their free time as representatives for an association, while others were employed professionals at the municipality, and participated as part of their salaried work. Some had a formal responsibilities and mandates within the FL, whereas others were users with in-depth, long-term, local 
knowledge. Given the focus on GBI resilience in this $\mathrm{pRT}$ process, the stakeholders concerned about, or responsible for, the urban GBI and nature-based recreation activities were the easiest to engage. It was harder to convince actors engaged with or responsible for seemingly peripheral preconditions for access or activities, e.g., not directly GBI, or at other levels than FL, to participate. Consequently, the participants as a group were, with regard to both knowledge and engagement, biased toward certain aspects of the system. In the FL case, the risk would be a skewed understanding of the system dynamics biased toward the GBI, and where other important elements are less understood (e.g., other interests in the GBI, beyond biodiversity conservation and recreational use, details of the ongoing urbanization or infrastructural developments), and hence not incorporated in the proposed interventions. It might also have promoted a polarized view, where important preconditions are perceived as external and easy to frame as threats instead of internal system dynamics that can be influenced.

\section{Bridging sectors and discourses}

A pRT process must recognize that it always starts in a context of pre-existing knowledge and ongoing practice and interactions that are more or less visible, complex, and active. Therefore, the first steps of a pRT process have a lot to do with tailoring the process to the case, and its different planning processes, conflicts, alternative visions, and values, as well as important events. Knowledge about these is necessary to become a relevant stakeholder as a researcher, and to design a process that is relevant to all different stakeholders, researchers included. A substantial part of the system mapping in phase 1 for the FL process concerned the governance layer, which included identification of stakeholders and their interactions and roles, as well as policies and decision-making processes and procedures. This is a crucial step in all pRT processes, but it becomes more demanding in the urban setting with its small-scale heterogeneity of land uses, coproduction of GBI benefits, and institutional thickness.

With high diversity of stakeholders and a primarily discussionbased process, considerable efforts were necessary to bridge across multiple differences. An often-discussed challenge in transdisciplinary processes or science-policy interfaces is the translation of terminologies (concepts and frameworks) to make it accessible to the participants (Lang et al. 2012, Sarkki et al. 2014). A decision was made by the researcher team to use the concepts "nature-based recreational activities," "preconditions for access," and "users," which was a way to translate the conceptual model (Andersson et al. 2019) to existing terminology in GBI policy and practice in the FL. The assumption was that this terminology would be a concrete and common ground for bridging divides between the participants (Trompette and Vinck 2009, De Vreese et al. 2019). However, "nature-based recreational activities" as a conceptual framing is strongly related to traditional uses of GBI and the nature protection discourse in Sweden. Even if the concept bridges the nature conservation and outdoor recreation sectors, both share this discourse as a way to articulate the values of GBI. Preconditions were used to ameliorate this bias, although non-GBI components and processes were more difficult to include in the discussions (e.g., Erixon et al. 2013). During the process, there was also a clear clarity-complexity trade-off, as described by Sarkki et al. (2014). The pRT ambition to address system complexity was curbed by use of these common, concrete denominators aimed to ensure a high level of inclusivity in the participatory dialogues. Frequent and substantial processing by the researcher team in-between the participatory activities in the process was the main strategy for finding ways to re-include the whole landscape and its complexity (Fig. 2).

\section{From external threats to internal dynamics}

Phase 2 of the pRT process was very challenging and needed two workshops that framed change in the FL in slightly different ways. In the first workshop in this phase (WS2 in Fig. 2) the identified drivers of change from phase 1 were explored by the development of several scenarios. At this workshop, several of the participants expressed hesitation because they found themselves having limited knowledge about or experience of certain drivers and even less knowledge about how these drivers might interact. The participants found the second workshop in this phase (WS3 in Fig. 2, Appendix 2) about change easier, where they discussed how scenarios developed by the research team would influence the nature-based recreational activities. We see three possible reasons to why system dynamics and change were difficult to engage with; first, the lack of direct experiences of change and clear examples of what change might mean in the FL; second, the strong polarization of GBI preservation versus urbanization among the participants; and third, a lack of tools in the pRT approach for addressing change in complex urban settings.

The kind of dynamics that is incorporated and further processed in a pRT process is strongly influenced by and dependent on the understanding and experiences among the participants (Walker et al. 2004, Andrachuk and Armitage 2015). Some systems are perceived as changing radically and rapidly at large scales (e.g., flooding, disease outbreak, economic recession), which might effectively hide more incremental and slow changes (e.g., increased precipitation, species decline, new resource uses, small scale urbanization). Cities are characterized by different internal and external dynamics at different spatial and temporal scales, and related to different parts or aspects of the system (McPhearson et al. 2016, Alberti et al. 2018). Internally, cities are characterized by frequent changes in, for example, land use, human habits, and economy, while at the same time dominant components, e.g., buildings, roads, and other physical infrastructures, are robust to a certain magnitude of changes (Walker 2000, Kurth et al. 2019). Additionally, cities are often also characterized by being relatively disconnected from their supporting resource providing systems, where distance and/or advanced technology to some degree buffer against influence from changes in these systems (Seto et al. 2012, Porter et al. 2014).

From the perspective of this process, the FL can be described as a system perceived as changing incrementally and slowly, a situation that most likely can be found in many other urban settings, when functionality rather than physical shape is the target issue. From a pRT process viewpoint this was a difficult starting point because several of the participants did not see a need to build capacity to handle change, and/or did not see themselves as being part of that capacity building process, because the identified changes were perceived as external. Change was expressed as a rather abstract fear of negative impact from large-scale, external changes (climate change, national urbanization politics), and worries about its impact on the local level, as well as insufficient 
capacity in the present governance to handle these. This can be related to the long-term, and still ongoing, fight for GBI preservation against urbanization in the FL and GBI in other places in the city (Erixon et al. 2013, Andersson et al. 2014). The participants acknowledged that the GBI quantity is steadily decreasing, while its internal dynamics and potential qualitative changes were not recognized.

The main challenge for the researcher team in this phase was to design for and facilitate in-depth discussions about the internal dynamics of FL, and thereby broaden the perspective of change from being about external, abstract threats, to include internal system dynamics that can have both positive and negative outcomes in relation to the set target. Urban GBI under pressure from urbanization is likely a situation the FL shares with other landscapes in most cities, and thus this challenge will be an integral part and methodological challenge for pRT processes targeting GBI benefits in cities. Over time, especially in workshops 3 and 4 (Fig. 2, Appendix 2), the participants increasingly acknowledged that the FL had been and was changing and that the nexus of recreation activities-preconditions for access-users are part of this dynamic. However, it was difficult to bridge the difference in resolution between the rather abstract notion of drivers of change and detailed understanding of the different activities and users. A plausible reason for the difficulties in working with change and system dynamics is the governance fragmentation, where in-depth knowledge, about, for example, climate change impacts, or urbanization patterns, is held by specific sectors that were not initially thought of as stakeholders in the process. A relevant question then is if there is a need to perform additional stakeholder mapping, and if needed inclusion in the different steps of a pRT process. This might be particularly important in the multi-level, multi-actor urban context.

The researcher team also experienced that the models and concepts usually applied in pRT to disentangle complexity of change, such as adaptive cycles, multiple states, thresholds, and regime shifts were less useful. This was because the system addressed included a diversity of co-produced, nature-based recreational activities influenced by multi-dimensional changes, where it is hard to identify a specific state at that level of complexity. There is a clear need for other models, concepts, and tools that address change in settings characterized by SE co-production and multidimensionalities, such as urban landscapes (Elmqvist et al. 2018).

\section{Agency and collective action capacity}

For many pRT processes, a baseline assumption and implicit objective is that the improved system understanding will enable the participants to engage with the system in new ways (e.g., Sellberg et al. 2018). Improving the ability to work simultaneously with GBI benefits and their preconditions to balance multiple processes of constant or intermittent external and internal change requires a careful consideration of the governance options: what is done, how it is done, and by whom. Many studies point toward the need for multiple alternative actor coalitions and processes (e.g., Buijs et al. 2016, Bodin 2017), with new collaborative arrangements for allowing a larger diversity of actors and types of knowledge to inform strategies and decisions.

The need for collective action, as prescribed by many resilience scholars, was recognized by the participants. However, there were few concrete suggestions on how to change from current fragmented, compartmentalized governance. Sectoral and administrative boundaries were seen as one of the main barriers for better grounded or alternative ways for engaging with the urban landscape and the flow of GBI benefits. However, the participants found it challenging to discuss implications and connections beyond their specific geographical area of local knowledge, sphere of interest, or responsibility and mandate. It became very clear that the strong formal institutions together with somewhat rigid perceived roles and self-identities (professional and otherwise) in the FL were constraining multi-level and crosssector SE system thinking. Although the process included a diverse set of actors, most of them were reasoning from within a narrowly defined role or identity and had few concrete ideas for how to move beyond the present, e.g., through alternative roles, expanded mandates, or alternative ways of acting and interacting. Most of the suggested action points discussed were things considered outside the influence of the participants and as such things that should be undertaken by someone else, indicating a limited perceived agency. Participants representing an organization with formal responsibilities were often constrained by these, e.g., either acting at the geographical level of the FL but only within one sector, e.g., water management, or acting across sectors but within a narrow institutional frame, e.g., land use rights such as the allotment garden association or nature protected areas. Means and motivation for taking action, especially jointly, was a critical issue only partly addressed and amended by the pRT process, and the last step in the process, designing strategies, will need more time. Many of the beneficiaries of urban GBI benefits act (and seem to perceive themselves) as passive users of a system run by others, meaning they only react to decisions and do not actively engage in its development and capacity to handle change. A stronger participation of actors with knowledge and interest in processes rather than the structure and qualities of the landscape per se, could be one way to help progress discussions. Alternatively, as showed by De Luca et al. (2021, this Special Feature) focusing the pRT on a specific process, e.g., a new policy or local development plan, or working through several specific processes, and outcome could be another way to get closer to action.

\section{CONCLUDING INSIGHTS}

The application of pRT in a complex urban setting characterized by institutional thickness, governance fragmentation, and coproduced GBI benefits shows the following:

- Because of the character of the urban system, especially land use complexity and institutional thickness, deep knowledge and insight require the involvement of diverse stakeholders. To ensure that the process can meet its objectives, substantial effort needs to be put into mapping of relevant stakeholders, at several points throughout the process.

- There is a need for high-level competence in process design, facilitation, and leadership in order to handle the diversity of actors who need to be involved. Mixing open, interactive group activities, such as workshops, with wider intermediary consultation offers a way to engage with large heterogeneous groups.

- Together with the use of existing terminology as a bridging concept, the ambition of an inclusive process and the need to be relevant increase the risk of reducing the level of 
complexity of the deliberative process. Constant efforts by the process facilitators to question and unpack the use of terms and concepts and in between sessions, to theorize back to the underlying system conceptualization will help finding a workable level of complexity.

- A pRT process helps participants reflect on their individual and collective agency, but the depth of the reflection depends on the composition of the group and the individual's position in and approach to the targeted system.

- There is a high risk of participation bias, where stakeholders knowledgeable about the GBI and/or its benefits are easier to engage, compared to stakeholders with knowledge about drivers of change, preconditions, and (urban) system governance, which will affect the system understanding and range and nature of alternative pathways for taking action.

- Systems with less visible/perceived/experienced changes may offer more difficulties in motivating stakeholders to engage in $\mathrm{pRT}$ in order to support a proactive capacity building process.

- The often strong protective attitude among GBI users and experts complicates the discussions about working with rather than against change, which is at the core of resilience thinking, and hence risk to hinder necessary capacity building efforts.

Responses to this article can be read online at: https://www.ecologyandsociety.org/issues/responses. php/12432

\section{Acknowledgments:}

We would like to acknowledge all stakeholders participating in the $p R T$ process of the Flaten landscape. Furthermore, we would like to acknowledge P. Isaksson, K. Fryers Hellquist, N. Bergame, J. Enqvist, and D. Enarsson for contributing as workshop assistants. We also would like to acknowledge the constructive feedback provided by two anonymous reviewers. This research was funded through the 2015-2016 BiodivERsA COFUND call for research proposals, with the national funders the Swedish Research Council for Environment, Agricultural Sciences, and Spatial Planning; the Swedish Environmental Protection Agency; the German Aerospace Center; the National Science Centre (Poland; grant no. 2016/22/ Z/NZ8/00003); the Research Council of Norway; and the Spanish Ministry of Economy and Competitiveness. The research was also funded by the Formas project number 2015-00734.

\section{Data Availability:}

The aggregated data that support the findings of this study are available on request from the corresponding author, SB. None of the primary data are publicly available because they contain information that could compromise the privacy of research participants. The kind of data collected does not require ethical approval by Swedish Law (SFS 2003:460). Following the principles of good research practice, informed consent was obtained from the research participants.

\section{LITERATURE CITED}

Alberti, M., T. McPhearson, and A. Gonzalez. 2018. Chapter 2: Embracing urban complexity. Pages 45-67 in T. Elmqvist, X. Bai, N. Frantzeskaki, C. Griffith, D. Maddox, T. McPhearson, S. Parnell, P. Romero-Lankao, D. Simon, and M. Watkins, editors. Urban planet. Cambridge University Press, Cambridge, UK. https://doi.org/10.1017/9781316647554.004

Amin, A., and N. Thrift. 1995. Globalization, institutional 'thickness' and the local economy. Pages 91-108 in P. Healey, S. Cameron, S. Davoudi, S. Graham, and A. Madani-Pour, editors. Managing cities: the new urban context. Wiley, Chichester, UK.

Andersson, E., S. Barthel, S. Borgström, J. Colding, T. Elmqvist, C. Folke, and Å. Gren. 2014. Reconnecting cities to the biosphere: stewardship of green infrastructure and urban ecosystem services. Ambio 43(4):445-453. https://doi.org/10.1007/s13280-014-0506y

Andersson, E., S. Borgström, D. Haase, J. Langemeyer, A. Mascarenhas, T. McPhearson, M. Wolff, E. Laszkiewicz, J. Kronenberg, D. N. Barton, and P. Herreros-Cantis. 2021b. A context sensitive systems approach for understanding and enabling ecosystem service realization in cities. Ecology and Society 26(2):35. https://doi.org/10.5751/es-12411-260235

Andersson, E., S. Borgström, D. Haase, J. Langemeyer, M. Wolff, and T. McPhearson. 2021a. Urban resilience thinking in practice: ensuring flows of benefit from green and blue infrastructure. Ecology and Society, Vol. 26 Iss. 4. in press.

Andersson, E., J. Enqvist, and M. Tengö. 2017. Stewardship in urban landscapes. Pages 222-238 in C. Bieling and T. Plieninger, editors. The science and practice of landscape stewardship. Cambridge University Press, Cambridge, UK. https://doi. org/10.1017/9781316499016.023

Andersson, E., J. Langemeyer, S. Borgström, T. McPhearson, D. Haase, J. Kronenberg, D. N. Barton, M. Davis, S. Naumann, L. Röschel, and F. Baró. 2019. Enabling green and blue infrastructure to improve contributions to human well-being and equity in urban systems. BioScience 69(7):566-574. https://doi. org/10.1093/biosci/biz058

Andersson, E., M. Tengö, T. McPhearson, and P. Kremer. 2015. Cultural ecosystem services as a gateway for improving urban sustainability. Ecosystem Services 12:165-168. https://doi. org/10.1016/j.ecoser.2014.08.002

Andrachuk, M., and D. Armitage. 2015. Understanding socialecological change and transformation through community perceptions of system identity. Ecology and Society 20(4):26. https://doi.org/10.5751/ES-07759-200426

Biggs, R., M. Schlüter, D. Biggs, E. L. Bohensky, S. BurnSilver, G. Cundill, Biggs, V. Dakos, T. M. Daw, L. S. Evans, K. Kotschy, A. M. Leitch, C. Meek, A. Quinlan, C. Raudsepp-Hearne, M. D. Robards, M. L. Schoon, L. Schultz, and P. C. West. 2012. Toward principles for enhancing the resilience of ecosystem services. Annual Review of Environment and Resources 37(1):421-448. https://doi.org/10.1146/annurev-environ-051211-123836 
Biggs, R., M. Schlüter, and M. L. Schoon, editors. 2015. Principles for building resilience: sustaining ecosystem services in socialecological systems. Cambridge University Press, Cambridge, UK. https://doi.org/10.1017/cbo9781316014240

Bodin, Ö. 2017. Collaborative environmental governance: achieving collective action in social-ecological systems. Science 357(6352):eaan1114. https://doi.org/10.1126/science.aan1114

Bolund, P., and S. Hunhammar. 1999. Ecosystem services in urban areas. Ecological Economics 29(2):293-301. https://doi. org/10.1016/S0921-8009(99)00013-0

Borgström, S. 2019. Balancing diversity and connectivity in multilevel governance settings for urban transformative capacity. Ambio 48:463-477. https://doi.org/10.1007/s13280-018-01142-1

Buijs, A. E., T. J. Mattijssen, A. P. Van der Jagt, B. Ambrose-Oji, E. Andersson, B. H. Elands, and M. Steen Møller. 2016. Active citizenship for urban green infrastructure: fostering the diversity and dynamics of citizen contributions through mosaic governance. Current Opinion in Environmental Sustainability 22:1-6. https://doi.org/10.1016/j.cosust.2017.01.002

Cash, D. W., W. C. Clark, F. Alcock, N. M. Dickson, N. Eckley, D. H. Guston, J. Jäger, and R. B. Mitchell. 2003. Knowledge systems for sustainable development. Proceedings of the National Academy of Sciences of the United States of America 100 (14):8086-8091. https://doi.org/10.1073/pnas.1231332100

De Luca, C., J. Langemeyer, S. Vaňo, F. Baró and E. Andersson 2021. Adaptive resilience of and through urban ecosystem services: a transdisciplinary approach to sustainability in Barcelona. Ecology and Society, Vol 26 Iss. 4. in press.

De Vreese, R., A. Van Herzele, N. Dendoncker, C. M. Fontaine, and M. Leys. 2019. Are stakeholders' social representations of nature and landscape compatible with the ecosystem service concept? Ecosystem Services 37:100911. https://doi.org/10.1016/ j.ecoser.2019.100911

Dickinson, D. C., and R. J. Hobbs. 2017. Cultural ecosystem services: characteristics, challenges and lessons for urban green space research. Ecosystem Services 25:179-194. https://doi. org/10.1016/j.ecoser.2017.04.014

Djenontin, I. N. S., and A. M. Meadow. 2018. The art of coproduction of knowledge in environmental sciences and management: lessons from international practice. Environmental Management 61:885-903. https://doi.org/10.1007/s00267-018-1028-3

Ehnert, F., N. Frantzeskaki, J. Barnes, S. Borgström, L. Gorissen, F. Kern, L. Strenchock, and M. Egermann. 2018. The acceleration of urban sustainability transitions: a comparison of Brighton, Budapest, Dresden, Genk, and Stockholm. Sustainability 10:612. https://doi.org/10.3390/su10030612

Elmqvist, T., E. Andersson, N. Frantzeskaki, T. McPhearson, P. Olsson, O. Gaffney, K. Takeuchi, and C. Folke. 2019. Sustainability and resilience for transformation in the urban century. Nature Sustainability 2(4):267-273. [online] URL: https://doi.org/10.1038/s41893-019-0250-1

Elmqvist, T., J. Siri, E. Andersson, P. Anderson, X. Bai, P. K. Das, T. Gatere, A. Gonzalez, J. Goodness, S. N. Handel, E. Hermansson Török, J. Kavonic, J. Kronenberg, E. Lindgren, D.
Maddox, R. Maher, C. Mbow, T. McPhearson, J. Mulligan, G. Nordenson, M. Spires, U. Stenkula, K. Takeuchi, and C. Vogel. 2018. Urban tinkering. Sustainability Science 13(6):1549-1564. https://doi.org/10.1007/s11625-018-0611-0

Enfors-Kautsky, E., L. Järnberg, A. Quinlan, and P. Ryan. 2018. Wayfinder: a resilience guide for navigating towards sustainable futures. GRAID programme, Stockholm Resilience Center, Stockholm University, Sweden. [online] URL: https://www. wayfinder.earth

Erixon, H., S. Borgström, and E. Andersson. 2013. Challenging dichotomies - exploring resilience as an integrative and operative conceptual framework for large-scale urban green structures. Planning Theory and Practice 14(3):349-372. https://doi. org/10.1080/14649357.2013.813960

Falardeau, M., C. Raudsepp-Hearne, and E. M. Bennett. 2019. A novel approach for co-producing positive scenarios that explore agency: case study from the Canadian Arctic. Sustainability Science 14(1):205-220. https://doi.org/10.1007/s11625-018-0620$\underline{Z}$

Folke, C. 2006. Resilience: the emergence of a perspective for social-ecological systems analyses. Global Environmental Change 16(3):253-267. https://doi.org/10.1016/j.gloenvcha.2006.04.002

Folke, C., S. Carpenter, T. Elmqvist, L. Gunderson, C. S. Holling, and B. Walker. 2002. Resilience and sustainable development: building adaptive capacity in a world of transformations. Ambio 3:437-440. https://doi.org/10.1579/0044-7447-31.5.437

Furberg, D. 2019. Satellite monitoring of urbanization and indicator-based assessment of environmental impact. Dissertation. KTH Royal Institute of Technology, Stockholm, Sweden.

Gómez-Baggethun, E., and D. N. Barton. 2013. Classifying and valuing ecosystem services for urban planning. Ecological Economics 86:235-245. https://doi.org/10.1016/j.ecolecon.2012.08.019

Grimm, N. B., E. M. Cook, R. L. Hale, and D. M. Iwaniec. 2015. A broader framing of ecosystem services in cities: benefits and challenges of built, natural or hybrid system function. Chapter 14 in K. C. Seto, W. D. Solecki, and C. A. Griffith, editors. The Routledge handbook of urbanization and global environmental change. Routledge, London, UK. https://doi.org/10.4324/9781315849256

Haase, D., N. Larondelle, E. Andersson, M. Artmann, S. Borgström, J. Breuste, E. Gomez-Baggethun, А. Gren, Z. Hamstead, R. Hansen, N. Kabisch, P. Kremer, J. Langemeyer, E. L. Rall, T. McPhearson, S. Pauleit, S. Qureshi, N. Schwarz, A. Voigt, D. Wurster, and T. Elmqvist. 2014. A quantitative review of urban ecosystem service assessments: concepts, models, and implementation. Ambio 43:413-433. https://doi.org/10.1007/ s13280-014-0504-0

Hansen, R., and S. Pauleit. 2014. From multifunctionality to multiple ecosystem services? A conceptual framework for multifunctionality in green infrastructure planning for urban areas. Ambio 43:516-529. https://doi.org/10.1007/s13280-014-0510-2

Hansen, R., A. Stahl Olafsson, A. P. N. Van Der Jagt, E. Rall, and S. Pauleit. 2019. Planning multifunctional green infrastructure for compact cities: What is the state of practice? 
Ecological Indicators 96(2):99-110. https://doi.org/10.1016/j. ecolind.2017.09.042

Healey, P. 1997. Collaborative planning. Shaping places in fragmented societies. MacMillan, London, UK.

Krasny, M. E., A. Russ, K. G. Tidball, and T. Elmqvist. 2014. Civic ecology practices: participatory approaches to generating and measuring ecosystem services in cities. Ecosystem Services 7:177-186. https://doi.org/10.1016/j.ecoser.2013.11.002

Kurth, M. H., J. M. Keenan, M. Sasani, and I. Linkov. 2019. Defining resilience for the US building industry. Building Research \& Information 47:480-492. https://doi.

org/10.1080/09613218.2018.1452489

Lang, D. J., A. Wiek, M. Bergmann, M. Stauffacher, P. Martens, P. Moll, M. Swilling, and C. J. Thomas. 2012. Transdisciplinary research in sustainability science: practice, principles, and challenges. Sustainability Science 7(S1):25-43. https://doi. org/10.1007/s11625-011-0149-X

Langemeyer, J., I. Palomo, S. Baraibar, and E. Gómez-Baggethun. 2018. Participatory multi-criteria decision aid: operationalizing an integrated assessment of ecosystem services. Ecosystem Services 30:49-60. https://doi.org/10.1016/j.ecoser.2018.01.012

Lavalle, C., N. Pontarollo, F. Batista, E. Silva, C. Baranzelli, C. Jacobs, B. Kavalov, M. Kompil, C. Perpiña Castillo, M. Vizcaino, R. Ribeiro Barranco, I. Vandecasteele, V. Pinto Nunes Nogueira Diogo, J.-P. Aurambout, C. Serpieri, M. Marín Herrera, K. Rosina, S. Ronchi, and D. Auteri. 2017. European territorial trends: facts and prospects for cities and regions. EUR $28771 \mathrm{EN}$, Publications Office of the European Union, Luxembourg. https:// doi.org/10.2760/28183

Leitch, A., G. Cundill, L. Schultz, and C. Meek. 2015. Principle 6 - Broaden participation. Pages 201-225 in R. Biggs, M. Schlüter, and L. Schoon, editors. Principles for building resilience: sustaining ecosystem services in social-ecological systems. Cambridge University Press, Cambridge, UK. https://doi. org/10.1017/cbo9781316014240.009

McPhearson, T., E. Andersson, T. Elmqvist, and N. Frantzeskaki. 2015. Resilience of and through urban ecosystem services. Ecosystem Services 12:152-156. https://doi.org/10.1016/j. ecoser.2014.07.012

McPhearson, T., D. Haase, N. Kabisch, and A. Gren. 2016. Advancing understanding of the complex nature of urban systems. Ecological Indicators 70:566-573. https://doi.org/10.1016/ j.ecolind.2016.03.054

Meerow, S., J. P. Newell, and M. Stults. 2016. Defining urban resilience: a review. Landscape and Urban Planning 147:38-49. https://doi.org/10.1016/j.landurbplan.2015.11.011

Munda, G. 2006. Social multi-criteria evaluation for urban sustainability policies. Land Use Policy 23(1):86-94. https://doi. org/10.1016/j.landusepol.2004.08.012

Pahl-Wostl, C. 2009. A conceptual framework for analysing adaptive capacity and multi-level learning processes in resource governance regimes. Global Environmental Change 19 (3):354-365. https://doi.org/10.1016/j.gloenvcha.2009.06.001
Palomo, I., M. R. Felipe-Lucia, E. M. Bennett, B. Martín-López, and U. Pascual. 2016. Disentangling the pathways and effects of ecosystem service co-production. Advances in Ecological Research 54:245-283. https://doi.org/10.1016/bs.aecr.2015.09.003

Pauleit, S., B. Ambrose-Oji, E. Andersson, B. Anton, A. Buijs, D. Haase, B. Elands, R. Hansen, I. Kowarik, J. Kronenberg, T. Mattijssen, A. Stahl Olafsson, E. Rall, A. P. N. van der Jagt, and C. Konijnendijk van den Bosch. 2019. Advancing urban green infrastructure in Europe: outcomes and reflections from the GREEN SURGE project. Urban Forest and Urban Greening 40:4-16. https://doi.org/10.1016/j.ufug.2018.10.006

Pickett, S. T. A. A., M. L. Cadenasso, and J. M. Grove. 2004. Resilient cities: meaning, models, and metaphor for integrating the ecological, socio-economic, and planning realms. Landscape and Urban Planning 69(4):369-384. https://doi.org/10.1016/j. landurbplan.2003.10.035

Plummer, R., and J. FitzGibbon. 2004. Co-management of natural resources: a proposed framework. Environmental Management 33(6):876-885. https://doi.org/10.1007/s00267-003-3038y

Polk, M. 2014. Achieving the promise of transdisciplinarity: a critical exploration of the relationship between transdisciplinary research and societal problem solving. Sustainability Science 9:439-451. https://doi.org/10.1007/s11625-014-0247-7

Porter, J. R., R. Dyball, D. Dumaresq, L. Deutsch, and H. Matsuda. 2014. Feeding capitals: urban food security and selfprovisioning in Canberra, Copenhagen and Tokyo. Global Food Security 3(1):1-7. https://doi.org/10.1016/j.gfs.2013.09.001

Resilience Alliance. 2010. Assessing resilience in social-ecological systems: Workbook for practitioners. Version 2.0. [online] URL: https://www.resalliance.org/files/ResilienceAssessmentV2 2.pdf

Sarkki, S., J. Niemelä, R. Tinch, S. van den Hove, A. Watt, and J. Young. 2014. Balancing credibility, relevance and legitimacy: a critical assessment of trade-offs in science-policy interfaces. Science and Public Policy 41(2):194-206. https://doi.org/10.1093/ scipol/sct046

Sellberg, M. M., S. T. Borgström, A. V. Norström, and G. D. Peterson. 2017. Improving participatory resilience assessment by cross-fertilizing the Resilience Alliance and Transition Movement approaches. Ecology and Society 22(1):28. https://doi. org/10.5751/ES-09051-220128

Sellberg, M. M., P. Ryan, S. Borgström, A. V. Norström, and G. D. Peterson. 2018. From resilience thinking to resilience planning: lessons from practice. Journal of Environmental Management 217:906-918. https://doi.org/10.1016/j.jenvman.2018.04.012

Sellberg, M. M., C. Wilkinson, and G. D. Peterson. 2015. Resilience assessment: a useful approach to navigate urban sustainability challenges. Ecology and Society 20(1):43. https:// doi.org/10.5751/ES-07258-200143

Seto, K. C., A. Reenberg, C. G. Boone, M. Fragkias, D. Haase, T. Langanke, P. Marcotullio, D. K. Munroe, O. Branislav, and D. Simon. 2012. Urban land teleconnections and sustainability. Proceedings of the National Academy of Sciences of the United States of America 109(20):7687-7692. https://doi.org/10.1073/ pnas. 1117622109 
Stockholm Stad. 2016. Stadens skyddade områden - en resurs stadsutvecklingen. Slutredovisning förstudie Pilot Flatens naturreservat. Stockholm Stad, Sweden. [online] URL: https:// vaxer.stockholm/globalassets/projekt/skarpnack-sdo/flaten-orhemskrubba/upprustning-av-entreerna-till-flatens-naturreservat/pilotflatens-naturreservat-slutrapport.pdf

Swedish Government. 2017. Strategi för Levande städer - politik för en hållbar stadsutveckling. Regeringens skrivelse 2017/18:230. Swedish Government, Stockholm, Sweden. [online] URL: https:// www.regeringen.se/4971fa/contentassets/b5640fd317d04929990610e1a20a5383/171823000webb.pdf

Tengö, M., E. S. Brondizio, T. Elmqvist, P. Malmer, and M. Spierenburg. 2014. Connecting diverse knowledge systems for enhanced ecosystem governance: the multiple evidence base approach. Ambio 43(5):579-591. https://doi.org/10.1007/ $\underline{\text { s13280-014-0501-3 }}$

Trompette, P., and D. Vinck. 2009. Revisiting the notion of boundary object. Revue d'anthropologie des connaissances 3 (1):3-25. https://doi.org/10.3917/rac.006.0003

Tuinstra, W., E. Turnhout, and W. Halffman. 2019. Usable knowledge. Pages 126-140 in W. Tuinstra, E. Turnhout, and W. Halffman, editors. Environmental expertise. Connecting science, policy and society. Cambridge University Press, Cambridge, UK. https://doi.org/10.1017/9781316162514.011

Turnhout, E., T. Metze, C. Wyborn, N. Klenk, and E. Louder. 2020. The politics of co-production: participation, power, and transformation. Current Opinion in Environmental Sustainability 42:15-21. https://doi.org/10.1016/j.cosust.2019.11.009

Walker, B., C. S. Holling, S. R. Carpenter, and A. Kinzig. 2004. Resilience, adaptability and transformability in social-ecological systems. Ecology and Society 9(2):5. https://doi.org/10.5751/ ES-00650-090205

Walker, B., and D. Salt. 2012. Resilience practice: building capacity to absorb disturbance and maintain function. Island, Washington, D.C., Washington, USA. https://doi.

org/10.5822/978-1-61091-231-0

Walker, W. 2000. Entrapment in large technology systems: institutional commitment and power relations. Research Policy 29:833-846. https://doi.org/10.1016/S0048-7333(00)00108-6

Wittmayer, J. M., and N. Schäpke. 2014. Action, research and participation: roles of researchers in sustainability transitions. Sustainability Science 9:483-496. https://doi.org/10.1007/ $\underline{\text { s11625-014-0258-4 }}$

Wolfram, M. 2016. Conceptualizing urban transformative capacity: a framework for research and policy. Cities 51:121-130. https://doi.org/10.1016/j.cities.2015.11.011

Wolfram, M. 2018. Cities shaping grassroots niches for sustainability transitions: conceptual reflections and an exploratory case study. Journal of Cleaner Production 173:11-23. https://doi.org/10.1016/j.jclepro.2016.08.044

Zhou, W., S. T. A. Pickett, and M. L. Cadenasso. 2017. Shifting concepts of urban spatial heterogeneity and their implications for sustainability. Landscape Ecology 32(1):15-30. https://doi. org/10.1007/s10980-016-0432-4 
Appendix 1. List of stakeholders participating in the participatory resilience thinking process in the Flaten landscape.

See Figure 2 for explanations to the the different steps in the process, WS = workshop. The numbers refer to the number of participants for each occasion. The number(s) in brackets (x) refers to the number of participants registered, but that had to cancel their participation for that particular occasion.

\begin{tabular}{|c|c|c|c|c|c|c|c|c|}
\hline Organisation & Role & $\begin{array}{l}\text { Key } \\
\text { informant }\end{array}$ & WS1 & Survey1 & WS2 & WS3 & WS4 & Interview \\
\hline $\begin{array}{l}\text { Stockholm municipality, The Environmental } \\
\text { Administration (Miljöförvaltningen) }\end{array}$ & Civil servant & 1 & 1 & 1 & 1 & 1 & 1 & 1 \\
\hline $\begin{array}{l}\text { Stockholm municipality, Skarpnäck city district } \\
\text { (Skarpnäck stadsdelsförvaltning) }\end{array}$ & Civil servant & 1 & 2 & 1 & 2 & 1 & 1 & \\
\hline $\begin{array}{l}\text { Stockholm municipality, The Urban Building Office } \\
\text { (Stadsbyggnadskontoret) }\end{array}$ & Civil servant & 1 & $1,(2)$ & 1 & $1,(1)$ & 1 & $1,(1)$ & 1 \\
\hline $\begin{array}{l}\text { Stockholm municipality, Tyresån water conservation } \\
\text { union (Tyresåns vattenvårdsförbund) }\end{array}$ & Civil servant & & 2 & & (1) & & (1) & 1 \\
\hline $\begin{array}{l}\text { Stockholm municipality, The Property Management } \\
\text { Office (Fastighetsförvaltningen) }\end{array}$ & Civil servant & & 1 & & 1 & (1) & 1 & 1 \\
\hline $\begin{array}{l}\text { Stockholm municipality, The Sports Administration } \\
\text { (Idrottsförvaltningen) }\end{array}$ & Civil servant & & (3) & & 1 & (1) & 1 & \\
\hline $\begin{array}{l}\text { Stockholm municipality, The Development Office } \\
\text { (Exploateringskontoret) }\end{array}$ & Civil servant & 1 & $1,(2)$ & & & & & \\
\hline $\begin{array}{l}\text { Stockholm municipality, The water and waste } \\
\text { company (Stockholm Vatten och Avfall) }\end{array}$ & Civil servant & 1 & & & & 1 & & \\
\hline
\end{tabular}


County Administrative Board in Stockholm County

Private environmental consultancy company

(Ekologigruppen)

Local company (café)

Youth association (Miljöverkstan)

Allotment associations (Listuddens

koloniträdgårdsförening, Skrubba

koloniträdgårdsförening

Sport associations, climbing \& archery (Solna

Klätterklubb, Storstockholms bågjägarskytte)

Environmental protection NGOs (Nacka

Miljövårdsråd, Söderorts Naturskyddsförening,

Föreningen Rädda Ältasjön)

Cultural history NGO (Nätverket Skarpnäcks Hembygd)

Local preschool (Filosofiska förskolan)
Consultant

Manager

Representative

Representative

Representative

Representative

Representative

Teacher

$1 \quad 1 \quad 1$

1

1

$2 \quad 2$

3

2

2,(1)

$221,(1)$

$5 \quad 2$


Appendix 2. Schematic workshop outline and overview of main questions per workshop and session.

\section{Schematic workshop outline}

Pre-workshop

\section{Workshop}

Introduction by the research team

Session 1

Break

Session 2

Closure by the research team

Post-workshop
Invitation sent out to participants by e-mail, including preparatory material and/or exercises (e.g. previous interaction documentations, new input or reflection points) and Registration of participants

Frame and aim of the pRT

Outcomes from previous interactions

Purpose of the workshop

Presentation of participants

Informed consent and other ethical issues clarified (e.g. photos, quotes)

Instruction and facilitation by research team Tasks to solve in smaller groups or individually, sharing of thoughts within smaller groups

Large group presentation and reflection, moderated by research team

Instruction and facilitation by research team Tasks to solve in smaller groups or individually, sharing of thoughts within smaller groups Large group presentation and reflection, moderated by research team

Summary of workshop insights

Information about next steps

Documentation processed and sent to all participants 
Summary of overarching questions per workshop and sessions

SESSION 1

SESSION 2

WORKSHOP 1: Understanding of GBI benefits and drivers of change

What should be resilient? What is valued?

Nature based recreational activities in FL Nature based recreational activities in relation to spatial outline of FL
Resilience to what? Changes and drivers of change.

Change on smaller and larger scales (time, space) of relevance to FL

Changes in relation to nature based recreational activities in FL

Importance of these changes in FL

\section{WORKSHOP 2: Exploring drivers of change}

Possible futures for FL $\mathbf{2 0 5 0}$

Creating narrative scenarios in relation to four drivers of change (urban development, environmental and climate change, forms of housing tenure, governance organisation and decision making)

How these scenarios impact the FL - the nature reserve and the surroundings
Evaluating the scenarios for FL 2050

Identifying threats and possibilities with the developed scenarios

\section{WORKSHOP 3: Assessing proposed scenarios}

Scenarios and nature based recreational activities

Influence of the four proposed scenarios on the nature based recreational activities, including both qualitative and quantitative effects
Ranking nature based recreational activities - what to prioritise?

Prioritising nature based recreational activities to be supported under each scenario Prioritising nature based recreational activities based on the current situation in FL Assessing differences between scenario and current situation prioritisations.

\section{WORKSHOP 4: Identifying key interventions}

What needs to happen and how to achieve the goals?

What in the present FL should be preserved, adapted and/or transformed, or removed?

What is the appropriate scale of intervention?
Who, where and when?

Who will implement the measures identified? Where can the measures be implemented? When should the measures be implemented? 
Appendix 3. Questions in surveys and interviews (See Figure 2 for process steps).

\section{SURVEY 1 QUESTIONS}

\section{Theme 1: Preconditions for activities in the Flaten landscape}

1. What preconditions are necessary for the following activities to take place in the Flaten landscape?

Pre-set preconditions: Transportation to and from; Service on site or nearby; Nature based preconditions; Specific permissions; Equipment; Specific knowledge/skills; Information; Do not know.

2. How important are different preconditions for the 20 activities taken together? Pre-set choices: Transportation to and from; Service on site or nearby; Nature based preconditions; Specific permissions; Equipment; Specific knowledge/skills; Information; Do not know.

3. What preconditions are important for the experiential value of the activity? Pre-set choices: Transportation to and from; Service on site or nearby; Nature based preconditions; Specific permissions; Equipment; Specific knowledge/skills; Information; Do not know.

4. How well are necessary preconditions catered for in the Flaten landscape? Pre-set choices: Well catered for; Somewhat catered for; Not catered for at all.

5. Are there other preconditions that were not included as possible answers in question $1-3$ ? Open-ended response.

\section{Theme 2: Changes in the Flaten landscape}

6. In what sense do you feel that you can influence these processes of change? Pre-set processes of change: Climate change; New exploitation/Densification; Mode of transport/Mobility infrastructure; Increased population/Change demographics; Priorities of public finances; Priorities of interventions in GBI; Planning and implementation of interventions in GBI.

Pre-set choices: A lot; Little; Not at all; Do not know

7. Where does this process of change occur most?

Pre-set processes of change: Climate change; New exploitation/Densification; Mode of transport/Mobility infrastructure; Increased population/Change demographics; Priorities of public finances; Priorities of interventions in GBI; Planning and implementation of interventions in GBI.

Pre-set choices: In the nature reserve; Outside the nature reserve; Equally inside as outside the nature reserve; Do not know.

8. What activities do you think are most sensitive to changes? Open ended response

9. What processes of change do you think has the largest impact on the following activities? 


\section{SURVEY 2 QUESTIONS}

1. What is your general impression of all workshops?

Pre-set choices: Very positive; Positive; Neutral; Negative; Very Negative

2. Was your expectations fulfilled during our workshops?

Pre-set choices: Yes, Partly, No, I do not know

3. Do you think that you have understood the purpose of the research?

Open-ended response.

4. What do you think of the number of workshops?

Pre-set choices: I would have liked more workshops; Good; I would have preferred fewer workshops; I have no opinion

5. How did you find the workshop design generally?

Multiple choices: It was hard to understand the exercises; I did not like the workshop design; It was easy to understand the exercises; The design was irrelevant; I have no opinion

6. Please provide specific feedback for different workshop parts, if you have some

7. What are the most important benefits of participating in a workhop where representatives from several different sectors meet to discuss the future of the Flaten landscape?

Open ended response.

8. What do you see as the most important deficits/challenges with participating in these kind of workshops?

Open ended response.

9. My understanding of the Flaten landscape has changes and I have gained new insights.

Pre-set choices: I completely agree, I partly agree; I am neutral; I partly disagree; I completely disagree.

10. The research and process were in line with other ongoing processes in the area. Pre-set choices: I completely agree; I partly agree; I am neutral; I partly disagree; I completely disagree.

11. I trust the other participants and could express my viewpoints during the discussions. Pre-set choices: I completely agree, I partly agree; I am neutral; I partly disagree; I completely disagree.

12. More and/or new collaborations have emerged between the participants in the workshops

Pre-set choices: I completely agree; I partly agree; I am neutral; I partly disagree; I completely disagree.

13. Have you had the possibility to contribute during the workshop $(s)$ ?

Multiple choices: Yes, a lot; Often; Sometimes; Partly during certain steps; No, not at all.

14. What was your main contribution during the discussions (e.g. local knowledge, ecological knowledge, knowledge about planning and practical management)? Open ended response.

15. What did you learn most from?

Pre-set choices: From the other participants; From the material distributed; From the presentations during the workshops; I do not know. 
16. Is there any organisation, representative or person that was not participating in the workshop $(s)$ and that should have been there?

Open ended response.

17. Has your view upon your own role in improving the Flaten landscape as part of a growing Stockholm changed during the workshop $(s)$ ? Open ended response.

18. What type of feedback from the continued research about the Flaten landscape are you interested in?

Pre-set choices: Written documentation, Invite researchers to present the research; I would like to engage further into the future of the Flaten landscape, but I do not know how; I am not interested in feedback from the research.

19. Is there anything you would like to add to the above responses?

Open ended response.

\section{INTERVIEW TOPICS}

- Enabling a more holistic and long-term governance of the Flaten landscape.

- What are the most important aspects?

- What actions are needed?

- How can these actions be implemented?

- Who are the key actors in that implementation?

- Reflection about the focus on changes and drivers of change in the pRT process.

- Reflection about the vision and goals that were developed within the pRT process.

- What are the most important key issues and challenge to achieve this vision?

- Is there anything missing in the formulated vision and goals?

- Reflection about the suggestion to develop an action plan for the Flaten landscape.

- What should be included?

- How should such plan be implemented?

- Who are the key actors?

- What are important starting points?

- Reflection about a pRT process initiated and hosted by a research team.

- How can such processes contribute?

- How can such processes be further improved?

- What is the role of the researcher in such processes? 
Appendix 4. List of key policy documents included in the initial scoping review.

Name [English translation]

RUFS 2050

[Regional Urban Development Plan]

Översiktsplan för Stockholm stad

[Comprehensive plan Stockholm municipality]

Tyresö 2035. Översiktsplan för Tyresö kommun

[Comprehensive plan Tyresö municipality]

Hållbar framtid i Nacka. Översiktplan för Nacka kommun.

[Comprehensive plan Nacka municipality]

Grönare Stockholm. Riktlinjer för planering, genomförande och förvaltning av stadens parker och naturområden.

[Greener Stockholm. Directions for planning, implementation and management of the urban parks and nature areas]

Den gröna promenadstaden.

[The green walkable city]

Sociotophandboken. Planering av det offentliga uterummet med stockholmarna och sociotopkartan

[Sociotope handbook]

Grönstrukturprogram Nacka kommun

[Green structure program Nacka municipality]
Type

Comprehensive

plan

Comprehensive

plan

Comprehensi

plan

Comprehensive

plan

Thematic

program

Thematic

program

Handbook

Thematic

program

\section{Sector}

Land use

Land use

(2.

Land use

and use

(a)

Green

structure

Green structure

Green

structure

Green

structure
Year Publisher

2018 Stockholm County

Council

2018 Stockholm municipality

2017 Tyresö municipality

2012 Nacka municipality

2017 Stockholm municipality

2013 Stockholm municipality

2003 Stockholm municipality

2011 Nacka municipality 
Upplevelsevärden in Nacka-Värmdökilen and Tyrestakilen

[Recreational values in Nacka-Värmdö and Tyresta green wedges]

Lokalt utvecklingsprogram för Skarpnäcks stadsdelsnämnd 20172027 [Local development program for Skarpnäck 2017-2027]

Parkplan Skarpnäck och Parkplan Farsta

[Park plans Skarpnäck and Farsta]

Åtgärdsprogram för Tyresån och Kalvfjärden 2016-2021

[Action plan for Tyresån and Kalvfjärden 2016-2021]

Program för Stora Sköndal

[Program for Stora Sköndal]

Detaljplaner Skarpnäcksgård och Solvärmen

[Detailed plans for Skarpnäcksgård and Solvärmen]

Detaljplaneprogram för Ältas nya centrum

[Detailed plan for Älta Center]

Detaljplaner Hedvigslund

[Detailed plans for Hedvigslund]

Beslut Flatens naturreservat

[Decision Flaten nature reserve]

Detaljerad skötsel vid Flatens naturreservat

[Suggested management of Flaten nature reserve]
Report

City district

program

City district plan

Management

program

City district

program

City district plan

City district plan

City district plan

Decision of

formal protection

Informal

management plan
Green

structures

Urban

development

Green

structure

\section{Blue}

structure

Urban

development

Urban development

2005

Urban

development

Urban

development

Green

structure

Green

structure
2004 Stockholm County

Council, Region-och

trafikplanekontoret

2016 Stockholm municipality

2007 Stockholm municipality

2016 Tyresåns

vattenvårdsförbund

2017 Stockholm municipality

Stockholm municipality

2015 Nacka municipality

2007 Nacka municipality

2007 Stockholm municipality

2001 Naturbyrån 
Stadens skyddade områden - en resurs i stadsutveckling.

Slutredovining förstudie Pilot Flaten naturreservat.

[The city protected areas - a resource in urban development. Final

report of pilot study Flaten nature reserve]

Utveckling av rekreationsvärden i Stockholms naturreservat.

Pilotstudie 2012: Hansta, Grimsta, Sätraskogen, Flaten,

Årstaskogen och Älvsjöskogen.

[Development of recreational valures in Stockholm nature reserves.

Pilot study 2012: Hansta, Grimsta, Sätraskogen, Flaten,

Årstaskogen and Älvsjöskogen.]

Besökare i Stockholms natur- och kulturreservat 2015. En

pilotundersökning med besöksräkning och besöksenkäter.

[Visitors in Stockholm nature- and culture reserves 2015. A pilot

investigation with visitor counting and surveys.]

\section{Project report}

Green

structure

Project report

Project report

Green

structure

Green

structure
2016

Stockholm municipality

2012

\section{Stockholm}

municipality,

Ekologigruppen $\mathrm{AB}$

015 Stockholm municipality 